\title{
TUTELA PROVISÓRIA: MODALIDADES, FUNGIBILIDADE E PODER GERAL DE CAUTELA ${ }^{1}$
}

\section{PROVISIONAL PROTECTION: MODALITIES, FUNGIBILITY AND GENERAL POWER OF CAUTION}

\author{
Jeferson Puel \\ Mestre em Administração (Conceito CAPES 3). \\ Universidade do Sul de Santa Catarina, UNISUL, \\ Brasil. Especialização em Pós Graduação Lato Sensu \\ em Gestão em Seguros. Especialização em Pós \\ Graduação em Direito Empresarial. (Carga Horária: \\ 450h). Fundação Universidade Regional de Blumenau, \\ FURB. Graduação em Direito. Fundação Universidade \\ Regional de Blumenau, FURB. Professor do curso de \\ Direito da Universidade do Sul de Santa Catarina \\ (Ecossistema Ânima). Assessor Jurídico lotado no \\ gabinete da Vara Regional de Recuperação Judicial, \\ Falências e Concordatas de Florianópolis (SC). \\ Florianópolis/SC. E-mail: jeferson.puel@hotmail.com
}

\section{Henrique Campos Nunes Born}

Graduado em Direito pela Universidade do Sul de Santa Catarina. Florianópolis/SC. Email: henriqueborn@hotmail.com

RESUMO: O conteúdo pesquisado neste artigo é a tutela provisória, de forma a abordar no início as suas modalidades de urgência e de evidência. Em seguida, verifica as regras comuns entre essas modalidades, como a sumariedade e a provisoriedade. Quanto a fungibilidade do pedido de tutela, demostra, em suma, como tornar eficaz o reconhecimento da tutela

\footnotetext{
${ }^{1}$ Artigo recebido em 29/08/2019 e aprovado em 16/08/2021.
} 
provisória. Por fim, além dos limites do poder geral de cautela, aborda a figura da contracautela no âmbito das tutelas provisórias. A técnica de pesquisa utilizada é a bibliográfica, baseada em doutrinas clássicas e modernas, e o método de pesquisa é o dedutivo.

PALAVRAS-CHAVE: Tutelas provisórias. Modalidades. Regras comuns. Fungibilidade. Poder geral de cautela.

ABSTRACT: The content researched in this article is provisional protection, to address, in the beginning, its urgency and evidence modalities. Then, it examines the common rules between these modalities, such as summary and provisionality. Regarding the fungibility of the request, it shows how to make the recognition of provisional protection effective. Finally, in addition to the limits of the general power of caution, it addresses the figure of countercaution in the context of provisional tutelage. The research technique used is bibliographic, based on classical and modern doctrines, and the research method is deductive.

KEYWORDS: Provisional protection. Modalities. Common rules. Fungibility. General power of caution.

SUMÁRIO: Introdução; 1. Modalidades; 1.1. Urgência; 1.2. Evidência; 2. Regras comuns às tutelas provisórias; 3. Fungibilidade; 4. Poder geral de cautela; 4.1. Limites; 4.2. Contracautela; Considerações Finais; Referências

\section{INTRODUÇÃO}

Diante da sociedade moderna e todas as suas relações sociais, permite-se compreender a importância do Direito Processual Civil inserido no contexto jurídico e social, em sintonia com a garantia constitucional. Frente às facilidades de comunicação e velocidade das informações, a tutela provisória está imersa no mundo jurídico para aprimorar a rapidez 
e eficiência do sistema processual, uma vez que a função jurisdicional tardia não se mostra útil para quem a procura ${ }^{2}$.

Sobre as tutelas provisórias, percebeu-se grande mudança a partir da nova modelagem do Código de Processo Civil, com a publicação da Lei 13.105. Com isso, formula-se como problemática quais são as modalidades de tutela provisória e as suas regras comuns de aplicabilidade.

Nesse sentido, verificar-se-á nessa pesquisa as modalidades das tutelas provisórias, as suas regras comuns, bem como a fungibilidade do pedido de tutela. Serão apresentados, ainda, os poderes do juiz no âmbito de reconhecimento da tutela provisória. Para tanto, foram utilizados como métodos de pesquisa o dedutivo e a técnica de pesquisa a bibliográfica.

\section{MODALIDADES}

O CPC trata das tutelas provisórias no Livro V, que se divide em 3 (três) Títulos: o primeiro trata das disposições gerais, o segundo da tutela de urgência e o terceiro da tutela de evidência. Dispõe o referido Código que surge da tutela provisória duas modalidades: a tutela de evidência e a de urgência, ambas com o intuito de adiantar os efeitos da sentença ou assegurar o resultado prático. ${ }^{3}$ Neste momento, tratar-se-á sobre essas modalidades para, em sequência, abordar os seus aspectos comuns.

\subsection{Urgência}

A tutela provisória de urgência justifica seu fundamento pelo quesito temporal, na medida em que o deferimento do pedido está condicionado ao convencimento do magistrado de que a duração da tramitação processual afigura em ônus à parte requerente, de modo a refletir em uma tutela jurisdicional definitiva ineficaz, em razão de não mais ser útil para a

\footnotetext{
${ }^{2}$ RIBEIRO. Leonardo Ferres da Silva. Tutela Provisória. In: WAMBIER, Luiz Rodrigues; WAMBIER, Teresa Arruda Alvim (coords.). Temas essenciais do novo CPC: análise das principais alterações do sistema processual civil brasileiro. São Paulo: Editora Revistas dos Tribunais, 2016. p. 178-179

${ }^{3}$ DONIZETTI, Elpídio. Curso didático do direito processual civil. 21. ed. São Paulo: Atlas, 2018. v. 1. p. 443
} 
parte ou em vias de perecer seu direito. ${ }^{4}$ Diante dessa situação emergencial, a maneira adequada para tutelar o direito é aquela baseada em cognição sumária. ${ }^{5}$

O CPC a divide em duas espécies: a tutela provisória de urgência cautelar e a antecipada, ambas com a possibilidade de requerimento em caráter antecedente, em momento anterior ao pedido principal, e incidente, em conjunto ou após o ajuizamento da petição inicial ou, ainda, em fase recursal. ${ }^{6}$ Em um primeiro momento, verifica-se a distinção entre a tutela cautelar e a antecipada, com foco na natureza conservativa e satisfativa.

Conforme Medina, os atos que visam garantir o resultado prático obtido pela atividade jurisdicional realizada através de outro pedido, futuro, compõem a tutela cautelar, ao passo que a tutela antecipada visa a fruição imediata dos efeitos do provimento jurisdicional definitivo. ${ }^{7}$ Explica Didier Júnior que ambas as modalidades visam antecipar os efeitos da tutela definitiva - realizada em cognição exauriente -, uma vez que a espera desta tutela definitiva pode caracterizar risco ao processo ou perigo de dano e, por isso, necessário tutelar em sede de cognição sumária. Assim, a tutela provisória antecipada visa satisfazer os efeitos pretendidos na decisão final, enquanto a cautelar assegura os efeitos da tutela definitiva, a fim de proteger, de início, a futura e eventual satisfação do direito pretendido. $^{8}$

As tutelas de urgência devem observar dois requisitos para concessão insculpidos nos artigos 300 e seguintes do CPC: o perigo de dano, em que a parte deve demonstrar a existência de risco de perecimento da pretensão que se espera à concessão da tutela, e a probabilidade do direito, revelada pela demonstração do interesse no direito de ação, das suas condições, bem como pela existência de fatos favoráveis fundados em alegações

\footnotetext{
${ }^{4}$ NEVES, Daniel Amorim Assumpção. Novo código de processo civil comentado. 2. ed. Salvador: JusPodivm, 2017. p. 486

${ }^{5}$ MARINONI, 1994 apud MELO, Manuel Maria Antunes de. Manual de direito processual civil. 2. ed. São Paulo: Edijur. 2016. p. 178

${ }^{6}$ SILVA, Jaqueline Mielke. A tutela provisória no novo Código de Processo Civil. 2. ed. Porto Alegre: Verbo Jurídico, 2016. p. 117

${ }^{7}$ MEDINA, José Miguel Garcia. Curso de direito processual civil moderno. 3. ed. São Paulo: Editora Revistas dos Tribunais, 2017. p. 481-482

${ }^{8}$ DIDIER JÚNIOR. Fredie; BRAGA, Paula Sarno; OLIVEIRA, Rafael Alexandre de. Curso de direito processual civil: teoria da prova, direito probatório, decisão, precedente, coisa julgada e tutela provisória. 13. ed. Salvador: Jus Podivm, 2018. v. 2. p. 647-648
} 
razoáveis, pelo qual o juízo, por meio do exame sumário da existência do direito, perquire pela plausibilidade e defere o pedido. ${ }^{9}$

No que diz respeito ao momento da postulação, o autor, ao invés de ingressar com a ação principal e requerer de forma incidental a tutela de urgência, pode o fazer antes da propositura da demanda, em caráter antecedente, de modo que formula o pedido condizente com a situação urgente para, em momento posterior, apresentar o pedido principal. Nessa ordem, efetivada a tutela provisória, conceder-se-á ao autor a oportunidade de aditamento do pedido antecedente a fim de adequar os elementos faltantes relativos ao pleito principal para, após, continuar nos mesmos autos o processamento deste. ${ }^{10}$ Ademais, uma vez efetivada a tutela provisória antecipada em caráter antecedente ${ }^{11} \mathrm{e}$ o réu não se manifestar sobre a cognição, não contestar ou não recorrer da decisão, estabilizar-se-á os seus efeitos. 12

Urge, a seguir, mencionar uma outra forma de tutela provisória instituída pelo legislador, pautada em requisitos mais objetivos que evidenciem o direito.

\subsection{Evidência}

Enquanto a "[...] tutela antecipada é a própria tutela de direito ambicionada pela parte mediante o exercício da ação [...]" e a "[...]cautelar é tutela de segurança do direito [...]", a tutela de evidência possui seu alicerce baseado na prova dos fatos constitutivos em que, por exemplo, houver defesa infundada do réu. Diferencia-se a tutela antecipada como uma medida com possibilidade de ser concedida antes de demonstrados os fatos constitutivos do direito do autor, de modo que pode ser asseverado e provado em momento posterior, hipótese

\footnotetext{
${ }^{9}$ THEODORO JÚNIOR, Humberto. Curso de direito processual civil: Teoria geral do processo civil, processo de conhecimento e procedimento comum. 59. ed. Rio de Janeiro: Forense, 2018. v. 1. p. 647-648

10 WAMBIER, Luiz Rodrigues; TALAMINI, Eduardo. Curso avançado de processo civil: cognição jurisdicional (processo comum de conhecimento e tutela provisória). 16. ed. São Paulo: Revista dos Tribunais, 2016. v. 2. p. 862; MOUZALAS, Rinaldo; TERCEIRO NETO, João Otávio; MADRUGA, Eduardo. Processo civil. 10. ed. Salvador: JusPodivm, 2018. p. 490; NEVES, Daniel Amorim Assumpção. Novo código de processo civil comentado. 2. ed. Salvador: Editora JusPodivm, 2017. p. 487

${ }^{11}$ Enunciado 420 do Fórum Permanente de Processo Civil: "Não cabe a estabilização de tutela cautelar" (DIDIER JÚNIOR. Fredie; BRAGA, Paula Sarno; OLIVEIRA, Rafael Alexandre de. Curso de direito processual civil: teoria da prova, direito probatório, decisão, precedente, coisa julgada e tutela provisória. 13. ed. Salvador: Jus Podivm, 2018. v. 2)

${ }^{12}$ MARINONI, Luiz Guilherme; ARENHART, Sérgio Cruz; MITIDIERO, Daniel. Código de processo civil comentado. 4. ed. São Paulo: Thomson Reuters Brasil, 2018. p. 417
} 
diversa do pedido liminar de mandado de segurança e de tutela de evidência, em que a postulação somente poderá ser deferida se instruída com as provas das alegações dos fatos constitutivos do direito. ${ }^{13}$

Por conseguinte, a tutela de evidência é aquela que não se justifica pela urgência, ou seja, não implica a comprovação do perigo de dano ou do risco ao resultado útil do processo. ${ }^{14}$ Tratam-se de "[...] situações em que o direito invocado pela parte se revela com um grau de probabilidade tão elevado, que se torna 'evidente'." 15 Segundo Assis: “[...] estampando-se a alta probabilidade de o autor ter razão, porque a isso induz o comportamento do réu ou logo se percebe da petição inicial, urge dar pronta resposta à postulação."16

Luiz Fux considera direito evidente aquelas situações:

em que se opera mais do que o fumus boni juris, mas a probabilidade de certeza do direito alegado, aliada à injustificada demora que o processo ordinário [comum] até a satisfação do interesse do demandante, com grave desprestígio para o Poder Judiciário, posto que injusta a espera determinada. ${ }^{17}$

Didier Júnior sustenta que o objetivo da tutela de evidência é redistribuir o ônus do tempo do processo, criado pela espera por uma tutela definitiva, uma vez que a comprovação, pelo autor, dos fatos apoiados em "alto grau de probabilidade" e a improvável defesa do réu suficiente para resistir com êxito à pretensão inicial, autoriza a conceder a tutela, em conformidade com o princípio da duração razoável do processo. ${ }^{18}$ Nesse sentido, Marinoni pontua ser uma técnica de distribuição do ônus do tempo, uma vez que demonstrada a evidência do direito pelo autor e a fragilidade da defesa do réu o acolhimento do pedido de

\footnotetext{
${ }^{13}$ MARINONI, Luiz Guilherme. Tutela de urgência e tutela da evidência. 2. ed. São Paulo: Thomson Reuters Brasil, 2018. p. 34; 41; 44

${ }^{14}$ GONÇALVES, Marcos Vinicius Rios. Novo curso de direito processual civil: teoria geral e do processo de conhecimento. 15. ed. São Paulo: Saraiva, 2018. v. 1. p. 351

${ }^{15}$ RIBEIRO. Leonardo Ferres da Silva. Tutela Provisória. In: WAMBIER, Luiz Rodrigues; WAMBIER, Teresa Arruda Alvim (coords.). Temas essenciais do novo CPC: análise das principais alterações do sistema processual civil brasileiro. São Paulo: Editora Revistas dos Tribunais, 2016. p. 211

${ }^{16}$ ASSIS, Araken de. Processo civil brasileiro: parte geral: institutos fundamentais. 2. ed. São Paulo: Revista dos Tribunais, 2016. v. 2. p. 499

${ }^{17}$ FUX, Luiz. A tutela dos direitos evidentes. Jurisprudência do Superior Tribunal de Justiça, Brasília, ano 2, número 16, p. 23-43, abril de 2000. Disponível em: 〈https://bit.ly/2yDJyxt>. Acesso em: 27 set. 2018

${ }^{18}$ DIDIER JÚNIOR. Fredie; BRAGA, Paula Sarno; OLIVEIRA, Rafael Alexandre de. Curso de direito processual civil: teoria da prova, direito probatório, decisão, precedente, coisa julgada e tutela provisória. 13. ed. Salvador: Jus Podivm, 2018. v. 2. p. 711
} 
tutela de evidência permite reduzir, ainda que em cognição não exauriente, o tempo destinado para o conhecimento do pleito inaugural. ${ }^{19}$

A evidência se resume na concepção de proteção jurisdicional de determinadas situações, em que as afirmações de direito e de fato conferem maior probabilidade ao autor merecer a prestação jurisdicional. ${ }^{20}$ Essas situações estão elencadas no artigo 311 do CPC: a abusividade do direito de defesa ou manifesto propósito protelatório da parte, o caráter punitivo desta hipótese visa corrigir o uso indevido do processo, uma vez que o comportamento abusivo e/ou protelatório do réu evidencia a probabilidade de o autor ser vitorioso. A segunda situação é perfectível quando o pedido, baseado em prova documental, possui tese firmada em julgamento de casos repetitivos ou súmula vinculante, diz respeito a vinculação do julgador a tese jurídica decidida em precedente obrigatório. ${ }^{21}$

$\mathrm{Na}$ terceira hipótese, o pedido reipersecutório fundado em prova documental adequada ao contrato de depósito, consiste na pretensão a uma prestação jurisdicional para que se entregue o bem depositado, sob pena de multa. E, por último, trata do pedido instruído com prova documental suficiente dos fatos constitutivos do direito a que o réu não oponha prova capaz de gerar dúvida, em que, diante de uma comprovação idônea, presume-se a falta de argumentos na defesa para desconstruir a pretensão autoral. ${ }^{22}$

Com isso, serão apresentadas, a seguir, as regras comuns às tutelas provisórias.

\section{REGRAS COMUNS ÀS TUTELAS PROVISÓRIAS}

A sumariedade representa a primeira semelhança entre essas categorias de tutela provisória. Diz respeito a um tipo de tutela jurisdicional realizada por uma cognição incompleta e superficial, incapaz de definir a lide definitivamente. ${ }^{23}$ Segundo Watanabe a convicção do juiz deve ponderar a "[...] intensidade do juízo de probabilidade no momento da avaliação, a natureza do direito alegado, a espécie dos fatos afirmados, a natureza do

\footnotetext{
${ }^{19}$ MARINONI, Luiz Guilherme. Tutela de urgência e tutela da evidência. 2. ed. São Paulo: Thomson Reuters Brasil, 2018. p. 278-279

${ }^{20}$ BUENO, Cassio Escarpinella. Manual de direito processual civil. 4. ed. São Paulo: Saraiva. 2018. p. 308

${ }^{21}$ SILVA, Jaqueline Mielke. A tutela provisória no novo Código de Processo Civil. 2. ed. Porto Alegre: Verbo Jurídico, 2016. p. 161-164

22 RIBEIRO. Leonardo Ferres da Silva. Tutela Provisória. In: WAMBIER, Luiz Rodrigues; WAMBIER, Teresa Arruda Alvim (coords.). Temas essenciais do novo CPC: análise das principais alterações do sistema processual civil brasileiro. São Paulo: Editora Revistas dos Tribunais, 2016. p. 213

${ }^{23}$ GRECO, Leonardo. Instituições de processo civil. 5. ed. Rio de Janeiro: Forense, 2015. v. 1. p. 365
} 
provimento a ser concedido, enfim, a especificidade do caso concreto." ${ }^{24}$ Por conta disso, afirma Theodoro que a tutela provisória não comporta a constituição de coisa julgada, uma vez que, diante de uma situação de emergência, não pretende a parte a composição do litígio mas o fim da onerosidade experimentada. Caracteriza-se como uma solução precária destinada a durar até a prolação de uma futura solução definitiva. ${ }^{25}$

Por consequência, extrai-se da lição de Gonçalves que, em sede de cognição sumária, podem ser deferidas em caráter liminar as tutelas de evidência, nas hipóteses dos incisos II e III do artigo 311 do CPC, e de urgência, com fundamento no artigo 300, §2 $2^{\circ}$ do CPC. Convém afirmar que o termo liminar, apesar de originado do latim, correspondente à expressão ab initio, que significa conceder algo no início de um processo. Esse conceito, utilizado na legislação vigente, refere-se ao momento anterior ao comparecimento do réu no processo, antes da citação do demandado. ${ }^{26}$

Nessa linha, a provisoriedade da tutela diz respeito à duração do tempo que a emergência necessita para ser tutelada, se fundada pela urgência até cessar o risco de dano ou ao resultado útil do processo, ou se fundada pela evidência até que a plausibilidade dos motivos seja desconstituída ou que seja prolatado provimento judicial definitivo. Ademais, uma vez concedida ou denegada a tutela, poderá ser alterada a decisão, a qualquer tempo, na hipótese de superveniência de fatos novos conduzirem o magistrado a ponderar pela revisão da situação e prolatar nova decisão. ${ }^{27}$

Dessas características decorre a instrumentalidade "[...] de tal modo que a tutela provisória, de urgência ou de evidência será [...] considerada uma função acessória em relação a uma outra modalidade de tutela, cognitiva ou executiva." ${ }^{28}$ Exemplifica essa característica a definição do juízo de processamento que, de acordo com o artigo 299 do CPC, será competente para apreciação do pedido incidental o juízo da causa, assim como os requerimentos de caráter antecedente devem observar ao juízo com atribuição para julgar o

\footnotetext{
${ }^{24}$ WATANABE, Kazuo. Da cognição do processo civil. 2. ed. Campinas: Bookseller, 2000. p. 128

25 THEODORO JÚNIOR, Humberto. Curso de direito processual civil: Teoria geral do processo civil, processo de conhecimento e procedimento comum. 59. ed. Rio de Janeiro: Forense, 2018. v. 1. p. 638

${ }^{26}$ GONÇALVES, Marcos Vinicius Rios. Novo curso de direito processual civil: teoria geral e do processo de conhecimento. 15. ed. São Paulo: Saraiva, 2018. v. 1. p. 331-332

${ }^{27}$ WAMBIER, Luiz Rodrigues; TALAMINI, Eduardo. Curso avançado de direito processual civil: Teoria Geral do Processo e Processo de Conhecimento. 15. ed. São Paulo: Revista dos Tribunais, 2016. v. 1. p. 875

${ }^{28}$ GRECO, Leonardo. Instituições de processo civil. 5. ed. Rio de Janeiro: Forense, 2015. v. 1. p. 361
} 
pedido principal. ${ }^{29}$ Quando se tratar de tutela requerida aos Tribunais, deverá se endereçar ao órgão jurisdicional competente, de acordo com o regimento interno de cada Tribunal. ${ }^{30}$

Leciona Wambier e Talamini que as tutelas provisórias precisam observar a reversibilidade das consequências ocasionadas no plano fático, ou seja, deve haver a possibilidade de se retornar ao estado anterior à efetivação da medida, status quo ante. Pode haver tanto o retorno ao estado anterior das coisas, ao qual se verifica mais ênfase no texto normativo, como também a reposição por indenização em valor pecuniário apto a compensar os danos sofridos. Entretanto, em certos casos irreversíveis não há como mensurar o valor como, por exemplo, de uma casa muita antiga que, por possuir valor histórico, não é possível substituir por pecúnia. Desse modo, deve ser averiguada, com base na proporcionalidade, qual o bem jurídico deverá prevalecer em prol de outro. Essa hipótese é expressa à tutela provisória fundada na urgência, nos termos do artigo $300, \S 2^{\circ}$ do CPC, embora seja possível a aplicação às tutelas fundadas em evidência. ${ }^{31}$

As decisões interlocutórias relativas à tutela provisória podem ser combatidas por meio de recurso de Agravo de Instrumento, com fundamento no artigo 1.015, I do CPC. Ressalta-se a inexistência, via de regra, do efeito suspensivo nesses recursos, o que viabiliza a execução provisória da decisão. Segue a mesma linha de raciocínio, quando o magistrado confirma, concede ou revoga a tutela em decisão definitiva - sentença. Nesse caso, o recurso cabível é de Apelação, sem efeito suspensivo no capítulo relativo à tutela provisória. ${ }^{32}$

Desse modo, concedida a tutela provisória, relevante fixar na prática, os meios para a sua efetivação, de maneira a concretizar os efeitos da decisão. Por meio do poder geral de cautela, o juízo, para garantir a realização da tutela, utilizará a maneira que entender mais adequada. Nessa linha, o magistrado possui ampla liberdade para definir as medidas

\footnotetext{
${ }^{29}$ MOUZALAS, Rinaldo; TERCEIRO NETO, João Otávio; MADRUGA, Eduardo. Processo civil. 10. ed. Salvador: JusPodivm, 2018. p. 472

${ }^{30}$ BUENO, Cassio Escarpinella. Manual de direito processual civil. 4. ed. São Paulo: Saraiva. 2018. p. 287

${ }^{31}$ WAMBIER, Luiz Rodrigues; TALAMINI, Eduardo. Curso avançado de direito processual civil: Teoria Geral do Processo e Processo de Conhecimento. 15. ed. São Paulo: Revista dos Tribunais, 2016. v. 1. p. 874875

32 DONIZETTI, Elpídio. Curso didático do direito processual civil. 21. ed. São Paulo: Atlas, 2018. v. 1. p. $451-452$
} 
consideradas necessárias para o caso, inclusive pode alterá-la se o meio utilizado for insuficiente ou se resultar em excesso para a outra parte. ${ }^{33}$

Segundo Araken de Assis, da efetivação da tutela de urgência pode haver responsabilização se resultar em dano ao réu, uma vez que "[...] ao pleitear a mudança do estado de fato, o litigante assume o risco de indenizar [...]". Acrescenta que a responsabilidade decorre da lei e deve se perfectibilizar em uma das hipóteses do artigo 302 do CPC, de maneira que não se perquire acerca da existência da culpa. Após o réu vencer a demanda, deverá comprovar, nos autos da ação, a existência do dano e a quem imputa o dever de ressarcir. De modo contrário, se da concretização da medida o réu vencedor auferir vantagem, não haverá indenização como, por exemplo, na hipótese de constrição de produtos que venha a impedir a exportação em um período e aumentar o preço no mercado, de modo que, cessada a constrição a venda no comércio exterior, resulta em lucro para o réu. ${ }^{34}$

Para Neves trata-se da teoria do risco-proveito, pois para o requerente a efetivação da medida torna-se muito proveitosa e, por outro lado, este possui o risco de ser considerado responsável pela medida concedida em cognição sumária. Sustenta que também se aplica a responsabilidade objetiva às tutelas de evidência, dado que, de igual modo, a efetivação da medida pode causar danos à parte contrária e, se revogada, o beneficiário deverá ressarcir as perdas e danos. ${ }^{35}$

Articulam-se outras regras comuns entre as tutelas provisórias, como a isenção de custas, a obrigatoriedade do requerimento da medida pela parte e o dever de motivação das decisões que concederem, negarem, modificarem ou revogarem a tutela. ${ }^{36}$ Nos casos em que as tutelas forem solicitadas em caráter incidental, a parte deverá adimplir as custas do processo no momento de ajuizamento da ação principal. Ressalta-se que o artigo 299 do CPC determina que a tutela provisória será requerida ao juízo da causa competente, de modo que

\footnotetext{
${ }^{33}$ MEDINA, José Miguel Garcia. Curso de direito processual civil moderno. 3. ed. São Paulo: Revistas dos Tribunais, 2017. p. 480; MOUZALAS, Rinaldo; TERCEIRO NETO, João Otávio; MADRUGA, Eduardo. Processo civil. 10. ed. Salvador: JusPodivm, 2018. p. 469

${ }^{34}$ ASSIS, Araken de. Processo civil brasileiro: parte geral: institutos fundamentais. 2. ed. São Paulo: Revista dos Tribunais, 2016. v. 2. p. 482-485

${ }^{35}$ NEVES, Daniel Amorim Assumpção. Novo código de processo civil comentado. 2. ed. Salvador: Editora JusPodivm, 2017. p. 505

${ }^{36}$ THEODORO JÚNIOR, Humberto. Curso de direito processual civil: Teoria geral do processo civil, processo de conhecimento e procedimento comum. 59. ed. Rio de Janeiro: Forense, 2018. v. 1. p. 642-643
} 
não é adequada a concessão de ofício. Quanto ao dever de motivar, justifica-se para evitar a prolação de decisões com fundamentos genéricos. ${ }^{37}$

Nesse sentido, diante da sistemática processual vigente, não se revela apropriada a concessão de ofício das tutelas provisórias, em razão dos princípios da cooperação e da vedação das decisões surpresas. Primeiro porque a concessão de ofício denota interpretação contrária à participação dos sujeitos processuais do início ao fim do processo, de forma que a concessão de ofício pelo juiz retiraria esse caráter processual. Segundo porque há necessidade de respeitar o contraditório das partes em qualquer momento, a vedar uma decisão inesperada nos autos, inclusive em matéria de ofício. ${ }^{38}$ Apresentados os pontos comuns das tutelas provisórias, considera-se essencial tratar em maior profundidade a fungibilidade.

\section{FUNGIBILIDADE}

As técnicas cautelar e antecipada são espécies do gênero tutela jurisdicional de urgência que, por sua vez, objetiva evitar a propagação dos efeitos do tempo de modo a resultar em dano ao direito da parte. A semelhança entre as duas modalidades pode gerar equívoco das partes ao requerer a medida, de maneira que o CPC estabeleceu no artigo 305, parágrafo único, a possibilidade de o pedido de tutela cautelar ser caracterizado como antecipação de tutela, ao qual observará o procedimento relativo a este. ${ }^{39}$ Desta determinação exsurge o debate sobre a característica fungível das tutelas, uma vez que se assemelham em diversos pontos - tratados no tópico anterior.

Denota Amendoeira Júnior, em respeito a fungibilidade, a existência de dois tipos: o primeiro, denominado de "fungibilidade como escolha", quando a parte possui a faculdade para escolher o meio, ou seja, o fim será alcançado independente do meio escolhido como, por exemplo, na ação de manutenção de posse o juiz pode conceder a medida de reintegração se entender a transgressão como esbulho e não turbação. Quanto ao segundo, denominado

\footnotetext{
${ }^{37}$ PINHO, Humberto Dalla Bernardina de. Direito processual civil contemporâneo: teoria geral do processo. 8. ed. São Paulo: Saraiva Educação. 2018. p. 571

${ }^{38}$ CARACIOLA, Andrea Boari; DELlORE, Luiz. Antecipação da Tutela Ex Oficcio. In: BUENO, Cássio Scarpinella (coord.). Tutela provisória no novo CPC. São Paulo: Saraiva, 2016. p. 118-119

39 BRASIL. Lei $\mathrm{n}^{\circ} 13.105$ de 16 de março de 2015. Código de Processo Civil. 2015 Disponível em: <https://bit.ly/1VojI3i> Acesso em: 25 out. 2018
} 
de "fungibilidade como conversão", não há essa indiferença, uma vez considerado pelo juiz, em sede de cognição, a incompatibilidade dos meios, pode ocorrer a conversão do meio escolhido pela parte para aquele que o magistrado entender adequado. Nesse sentido, a tutela de urgência abarcará as duas espécies de fungibilidade, na medida que, se a parte considera ambas as tutelas de igual natureza, optará por um dos procedimentos. Na hipótese de o magistrado entender inadequado converterá o meio utilizado. ${ }^{40}$

Salienta-se, ademais, não ser exclusivo das tutelas provisórias a aplicação do princípio da fungibilidade, de maneira que pode ser tratado em outros pontos do Processo Civil, como em demandas, ritos, provimentos e recursos. Verifica-se a característica comum da primazia pela essência, conteúdo e finalidade do ato e não pela forma, a refletir uma atuação menos rígida do magistrado. Assim, se o autor pede uma modalidade de tutela, similar àquela que deveria ser concedida, de modo a não prejudicar os efeitos futuros a que se pretende tutelar o bem jurídico, poderá se converter para a adequada. Por exemplo, o requerimento de tutela cautelar em vez da tutela possessória, como pretensão a conservação da posse ao possuidor de boa-fé. ${ }^{41}$

Desse modo, as modalidades cautelar e antecipada são meios para atingir a finalidade da demanda judicial, ou seja, a efetivação da tutela. Trata-se de duas espécies de técnicas correspondentes a uma tutela não definitiva, fundada em cognição sumária com a possibilidade de execução provisória. Dessa forma, apesar de protegerem o bem jurídico de maneira diversa, a flexibilização das técnicas converge para o fim a que se destina chegar: a tutela jurisdicional. ${ }^{42}$ Como exemplo, cita-se a sustação de protesto que parte da doutrina ${ }^{43}$ entende ser natureza cautelar, enquanto outros como natureza antecipatória de tutela. ${ }^{44}$

Didier Júnior direciona o princípio da fungibilidade à aplicação nas tutelas requeridas em caráter antecedente, na medida em que aquelas postuladas no decorrer da ação possuem

\footnotetext{
${ }^{40}$ AMENDOEIRA JÚNIOR, Sidnei. Fungibilidade de meios. São Paulo: Atlas, 2008. p. 133-134

${ }^{41}$ AMENDOEIRA JÚNIOR, Sidnei. Fungibilidade de meios. São Paulo: Atlas, 2008. p. 136-137

${ }^{42}$ LAMY, Eduardo de Avelar. Princípio da fungibilidade no processo civil. São Paulo: Dialética, 2007. p. 133135

${ }^{43}$ Cita-se as seguintes obras divergentes sobre o assunto: SPADONI, 2003 apud TARDIN, Luiz Gustavo. Fungibilidade das tutelas de urgência. São Paulo: Revistas dos Tribunais, 2006. p. 168-169; ZAVASCKI, Teori Albino. Antecipação da tutela. São Paulo: Saraiva, 2009. p. 58; VASCONCELOS, Rita de Cássia Corrêa de. Princípio da fungibilidade: hipóteses de incidência no processo civil brasileiro contemporâneo. São Paulo: Revista dos Tribunais, 2007. p. 305; SILVA, Ovídio A. Baptista da. A cautelar inominada no direito brasileiro. Rio de Janeiro: Forense, 1991. p. 391-392

${ }^{44}$ TARDIN, Luiz Gustavo. Fungibilidade das tutelas de urgência. São Paulo: Revistas dos Tribunais, 2006. p. 168-169
} 
o mesmo regime. A hipótese de o juiz receber a tutela antecipada como cautelar denominase de fungibilidade regressiva, pois parte da mais agressiva (antecipada) para a menos invasiva (cautelar). O contrário denomina de progressiva. Ambas devem observar o procedimento específico para a tutela, a converter eventual modalidade inadequada para aquela que é a adequada pela lei. ${ }^{45}$

Nesse sentido, Rita Vasconcelos ensina que a parte poderia cogitar de possível dúvida ao requerer uma tutela de urgência em caráter antecedente e não conseguir distinguir, diante dos fatos, qual a natureza jurídica, se cautelar ou satisfativa. Nesse momento, a fungibilidade se mostra de maior relevo, insculpida no parágrafo único do artigo 305 do $\mathrm{CPC}$, no sentido de permitir ao magistrado decidir qual a medida mais correta, em vista de existir diferentes procedimentos entre ambas. ${ }^{46}$ Por essa perspectiva, Medina estabelece que "[...] deve o magistrado interpretar o pedido apresentado pela parte, precisando seu real sentido, pouco importando a denominação empregada na petição inicial”, ou seja, o que de fato importa é a essência do pedido, qual a pretensão a ser tutelada. ${ }^{47}$

No tocante às tutelas provisórias em caráter antecedente, deve o requerente se atentar aos efeitos da aplicação da fungibilidade no seu pedido, em especial à estabilização da tutela. Na hipótese de o juiz entender que a tutela apropriada para o caso é de natureza satisfativa, adequará o procedimento àquele referente aos artigos 303 e seguintes do CPC e, por conseguinte, pode vir a serem estabilizados os efeitos da efetivação da medida no caso de deferimento. De modo diverso, quando o requerente pede a antecipação dos efeitos e o pedido é convertido em tutela cautelar, a estabilização futura pretendida não se concretizará, uma vez que não se aplica esta figura processual nas tutelas cautelares. ${ }^{48}$

Noutra vertente, Araújo se posiciona pela aplicação da fungibilidade em qualquer das modalidades de tutela provisória, apesar de inexistir previsão legal compatível à tutela de evidência. Desse modo, no decorrer da prática forense se pode observar requerimentos de tutelas em caráter liminar com características da tutela de evidência e de urgência. Neste

\footnotetext{
${ }^{45}$ DIDIER JÚNIOR. Fredie; BRAGA, Paula Sarno; OLIVEIRA, Rafael Alexandre de. Curso de direito processual civil: teoria da prova, direito probatório, decisão, precedente, coisa julgada e tutela provisória. 13. ed. Salvador: Jus Podivm, 2018. v. 2. p. 709-710

${ }^{46}$ VASCONCELOS, Rita de Cássia Corrêa de. A fungibilidade das tutelas provisórias. in: BUENO, Cássio Scarpinella (coord.). Tutela provisória no novo CPC. São Paulo: Saraiva, 2016. p. 447-448

${ }^{47}$ MEDINA, José Miguel Garcia. Curso de direito processual civil moderno. 3. ed. São Paulo: Revistas dos Tribunais, 2017. p. 480

${ }^{48}$ SOUZA, Artur César de. Tutela provisória: Tutela de Urgência e Tutela de Evidência. 2. ed. São Paulo: Almedina, 2017. p. 286
} 
sentido, o juiz estaria autorizado a conceder a tutela que entender como correta, independente da natureza, desde que respeitado os requisitos legais. ${ }^{49}$

Souza coaduna com esse posicionamento:

[...] se não há elementos para a concessão de uma tutela provisória de urgência satisfativa, por faltar, por exemplo, o 'periculum in mora', poderá o juiz, desde que presentes os demais requisitos, conceder uma tutela provisória de evidência, aplicando o princípio da fungibilidade entre as tutelas.

Da mesma forma, se a parte requerer uma tutela provisória de evidência, mas não preencher todos os requisitos exigidos para tal fim, poderá o juiz, de ofício, conceder uma tutela de urgência antecipada satisfativa, desde que a parte tenha demonstrado na sua petição a existência da probabilidade do direito e o perigo de dano ou o risco ao resultado útil do processo. ${ }^{50}$

Filia-se a esse entendimento Donizetti, para o qual confere legitimidade na hipótese de pedido de tutela de urgência quando a situação se afigura como de evidência, de modo que, para concedê-la, deve-se demonstrar os requisitos do artigo 311 do CPC. Nesse caso, dispensa-se a comprovação da urgência. Ao contrário, também poderia ser concedida a tutela de urgência se comprovado o perigo de dano ou risco ao resultado útil do processo, bem como a probabilidade de ser acolhido o pleito sustentado pela parte. ${ }^{51}$

Ademais, a conversão das técnicas não encerra diferença entre as espécies de tutelas, pois cada uma agrega uma característica diferente, a cautelar em conservar, a antecipada em satisfazer e a evidência em inverter o ônus do tempo probatório com base no direito evidente. O fato é que todas foram concebidas com o intuito de formar e otimizar o tempo para a formação do provimento jurisdicional definitivo. Quer dizer, interessa saber qual a situação urgente ou evidente para conceder uma medida que satisfaça ou assegure o direito lesado. Como também, não pode um pedido ser indeferido em razão da escolha equivocada da parte pela modalidade de tutela que, neste caso, há de ser adaptada de ofício pelo magistrado ao processamento correto do pedido. ${ }^{52}$

Desse modo, necessário tratar sobre a amplitude do poder geral de cautela.

\section{PODER GERAL DE CAUTELA}

\footnotetext{
${ }^{49}$ ARAÚJO, Fabio Caldas de. Curso de processo civil: parte geral. São Paulo: Malheiros, 2016. p. 965

${ }^{50}$ SOUZA, Artur César de. Tutela provisória: tutela de urgência e tutela de evidência. 2. ed. São Paulo: Almedina, 2017. p. 286

${ }^{51}$ DONIZETTI, Elpídio. Curso didático do direito processual civil. 21. ed. São Paulo: Atlas, 2018. v. 1. p. 456

${ }^{52}$ ARAÚJO, Fabio Caldas de. Curso de processo civil: parte geral. São Paulo: Malheiros, 2016. p. 966
} 
Sob o prisma do antigo regime processual existiam dois tipos de medidas para a tutela cautelar, as nominadas e as inominadas. O juiz, para tornar efetiva a medida ${ }^{53}$ concedida, possuía instrumentos ${ }^{54}$ previstos em lei, como também poderia criar maneiras para tutelar o direito além daquelas previstas em lei. A justificativa reside no fato de efetivar o direito pretendido pela parte. Evoluído o sistema processual com o advento do novo CPC, ampliouse a aplicação desses instrumentos às tutelas de urgência antecipada e para as tutelas de evidência, conforme disposto no artigo 297. 55

Significa conferir ao poder jurisdicional do juiz a disposição de uma plêiade de medidas, a exemplo da exibição de documentos, imposição de multa e busca e apreensão, que será confiado a sua ponderação, de modo que lhe caberá a escolha daquelas mais adequadas segundo a necessidade dos fatos. ${ }^{56}$ Mostra-se necessário, assim, verificar os limites desse poder.

\subsection{Limites}

Era assente, na legislação processual revogada, o princípio da tipicidade dos meios executivos, de forma que, deferida a tutela em cognição sumária, a lei dispunha de maneiras, ${\text { como o } \text { arresto }^{57} \text {, sequestro }}^{58}$, arrolamento de bens ${ }^{59}$ e protesto contra alienação $0^{60}$, para a

\footnotetext{
${ }^{53}$ A diferença entre medida cautelar e tutela cautelar para Souza é que esta traduz a concepção de provimento jurisdicional, enquanto a segunda diz respeito a exteriorização daquela, mediante atos concretos. (SOUZA, Artur César de. Tutela provisória: tutela de urgência e tutela de evidência. 2. ed. São Paulo: Almedina, 2017. p. 275)

${ }_{54}^{54}$ Cita-se os exemplos das notas de rodapé números 145 a 147.

${ }^{55}$ THEODORO JÚNIOR, Humberto. Curso de direito processual civil: Teoria geral do processo civil, processo de conhecimento e procedimento comum. 59. ed. Rio de Janeiro: Forense, 2018. v. 1. p. 663

${ }^{56}$ SOUZA, Artur César de. Tutela provisória: tutela de urgência e tutela de evidência. 2. ed. São Paulo: Almedina, 2017. p. 148; 274

57 “Arresto é a medida de apreensão de bens que tem por fim garantir futura execução por quantia certa. Ele incide sobre bens indeterminados e seu efeito principal é a afetação do bem apreendido enquanto a decisão não for modificada ou revogada.” (DONIZETTI, Elpídio. Curso didático do direito processual civil. 21. ed. São Paulo: Atlas, 2018. v. 1. p. 462)

${ }^{58}$ Sequestro é a medida cautelar típica pela qual apreende bens determinados, com intuito de assegurar a pretensão futura referente a obrigação de entregar coisa certa (MOUZALAS, Rinaldo; TERCEIRO NETO, João Otávio; MADRUGA, Eduardo. Processo civil. 10. ed. Salvador: JusPodivm, 2018. p. 488)

${ }^{59}$ Arrolamento de bens visa "[...] conservar bens sobre os quais incide o interesse do requerente da medida [...]", cria-se uma lista de bens a ser depositados. (DONIZETTI, Elpídio. Curso didático do direito processual civil. 21. ed. São Paulo: Atlas, 2018. v. 1. p. 462)

${ }^{60}$ Protesto contra alienação de bens é aquele em que o protestante alega ter algum direito sobre ele e torna essa declaração pública, a pretexto de contornar uma futura alegação de boa-fé (MOUZALAS, Rinaldo;
} 
realização da medida. Tratava-se de verdadeira limitação ao poder jurisdicional do magistrado, pois a prática se restringia aquelas medidas estipuladas na legislação. Verificase no modelo processual pretérito que a proteção de diversas situações era realizada por meios executivos determinados. Nesse ponto, denota-se a incongruência da lei, em razão da existência de multiplicidade de fatos tornando-se difícil esgotar as medidas necessárias à efetivação das tutelas, uma vez que cada situação possui uma peculiaridade específica. ${ }^{61}$

Desse modo, é pertinente explicar que as medidas típicas, não mais estipuladas no novo CPC, em virtude da amplitude dada ao poder geral de cautela, em nada influencia na apreciação dos pedidos formulados nas demandas judiciais, uma vez que o poder geral de cautela proporciona ao magistrado a oportunidade de deferir a medida julgada mais adequada para a situação reclamada. Trata-se da verificação do prisma da efetivação da medida, independente do meio utilizado. O que realmente importa é saber qual a necessidade da circunstância para, após, determinar a melhor medida. ${ }^{62}$

Dada a aplicabilidade deste poder às tutelas cautelares ou satisfativas, foi nomeado por Theodoro Júnior como "poder geral de prevenção". Trata-se de um poder com caráter discricionário para o qual deve o magistrado escolher, de acordo com suas convicções, a medida necessária para coibir o risco de dano durante o decorrer do processo. Desse modo, uma situação de perigo que vise impedir ou ameaçar o interesse da parte deverá ser reprimida por uma ordem, destinada ao responsável pelo ato comissivo ou omissivo, de maneira a perfectibilizar de forma negativa, para deixar de praticar algo, ou positiva, para praticar algum ato. ${ }^{63}$

Segundo Montenegro Filho, a nova roupagem do poder genérico permite, por exemplo, a imposição de multa diária (astreintes ${ }^{64}$ ). Considera uma medida eficiente, por criar uma situação em desfavor do demandado, para o qual possui duas opções: adimplir a

TERCEIRO NETO, João Otávio; MADRUGA, Eduardo. Processo civil. 10. ed. Salvador: JusPodivm, 2018. p. 488)

${ }^{61}$ MARINONI, Luiz Guilherme. Tutela de urgência e tutela da evidência. 2. ed. São Paulo: Thomson Reuters Brasil, 2018. p. 195-198

${ }^{62}$ DONIZETTI, Elpídio. Curso didático do direito processual civil. 21. ed. São Paulo: Atlas, 2018. v. 1. p. 462

${ }^{63}$ THEODORO JÚNIOR, Humberto. Curso de direito processual civil: Teoria geral do processo civil, processo de conhecimento e procedimento comum. 59. ed. Rio de Janeiro: Forense, 2018. v. 1. p. 664-665

${ }^{64}$ Traduz-se o termo do idioma francês como uma espécie de multa processual condicionada, via de regra, ao tempo de atraso para forçar o devedor a cumprir a obrigação. (HERTEL, Daniel Roberto. As astreintes e o novo Código de Processo Civil. Revista Jus Navigandi, Teresina, ano 23, n. 5407, 21 abr. 2018. Disponível em: <https://bit.ly/2TaoIyE> Acesso em: 8 nov. 2018.) 
obrigação específica ou suportar o encargo pecuniário da multa. $\mathrm{O}$ arbitramento deve ser realizado em consonância com o valor da obrigação, a configurar medida nem tão branda nem tão rígida, de modo a ser adequada. ${ }^{65}$

É relevante destacar a criação de critérios limitadores da atuação do juiz, quando da utilização do poder geral de cautela. Como mencionado, as medidas devem estar limitadas de acordo com a adequação, quer dizer, quais os meios se denotam idôneos para efetivar a tutela. Definidos aqueles adequados, deve ser escolhido o que resultar em menor onerosidade para o demandado ${ }^{66}$, de forma a restringir a liberdade do devedor somente ao necessário. Deve o magistrado observar, também, a dificuldade para satisfazer a tutela almejada, ou seja, o cenário dos fatos reflete de maneira considerável em deferimento de medida. Nesse diapasão:

[...] os postulados da adequação, da necessidade e da proporcionalidade em sentido estrito devem estruturar argumentativamente o emprego da técnica executiva a fim de que o poder judicial de escolha da técnica possa ser intersubjetivamente controlável. ${ }^{67}$

Denota-se, assim, para que a atuação do juiz, diante de uma situação de perigo, não invada a esfera privada da parte a qualquer modo. É injusto o magistrado se sobrepor às partes sem fundamento, de modo que deve exercer a função jurisdicional com a devida justificativa quanto a escolha da medida provisória. Assim, relevante o controle do poder geral de cautela a questão relacionada à fundamentação do raciocínio utilizado para conduzir a escolha da medida necessária e adequada. ${ }^{68}$ Desse modo, remete-se a utilidade em verificar o teor da contracautela.

\subsection{Contracautela}

\footnotetext{
${ }^{65}$ MONTENEGRO FILHO, Misael. Direito processual civil. 13. ed. São Paulo: Atlas, 2018. p. 285. Disponível em: <https://bit.ly/2EX19ZE> Acesso em: 20 de set. 2018 (Grifo do autor)

${ }^{66} \mathrm{O}$ princípio da menor onerosidade, insculpido no artigo 805 do $\mathrm{CPC}$, diz respeito a imposição de limite à execução, de maneira que a invasão na esfera patrimonial ou jurídica do devedor respeite a proporcionalidade. (SÁ, Renato Montans de. Manual de direito processual civil. 3. ed. São Paulo: Saraiva, 2018. p. 931)

${ }^{67}$ MARINONI, Luiz Guilherme; ARENHART, Sérgio Cruz; MITIDIERO, Daniel. Código de processo civil comentado. 4. ed. São Paulo: Thomson Reuters Brasil, 2018. p. 410

${ }^{68}$ MARINONI, Luiz Guilherme. Tutela de urgência e tutela da evidência. 2. ed. São Paulo: Thomson Reuters Brasil, 2018. p. 206-209; THEODORO JÚNIOR, Humberto. Curso de direito processual civil: Teoria geral do processo civil, processo de conhecimento e procedimento comum. 59. ed. Rio de Janeiro: Forense, 2018. v. 1. p. 667-668
} 
Em contrapartida ao poder de conceder uma medida cautelar, o pedido de tutela provisória de urgência pode gerar danos à parte demandada, na medida em que o magistrado, diante de cognição sumária, realiza um exame superficial da matéria aparentemente mais adequada de acordo com a demonstração da probabilidade do direito. Por essa razão, insculpiu-se o $\S 1^{\circ}$ do artigo 300 do CPC com o propósito de tornar exigível uma caução, diante do receio em prejudicar a parte com a concessão da tutela. ${ }^{69}$

Essa caução possui natureza de contracautela, uma vez que, proposta a medida pelo autor, a lei prevê uma garantia em favor do réu para assegurar o seu direito a indenização, se na hipótese da medida ser considerada posteriormente indevida e da execução sobrevir danos. ${ }^{70}$ Não quer dizer, sob esse ponto, que não haverá o reconhecimento pelo magistrado da existência de urgência do pedido e a probabilidade do direito, posto que nessa situação o pedido deveria ser indeferido. ${ }^{71}$

A caução é uma contracautela, pois assegura o direito da parte demandada na hipótese de haver modificação da decisão de concessão. Garante o ressarcimento às eventuais perdas e danos ocasionados pelos efeitos da concretização da medida. ${ }^{72}$ Câmara, ao tratar o tema, diz ser uma "[...] medida destinada a acautelar contra o assim chamado periculum in mora inverso, isto é, o perigo de que o demandado sofra, em razão da demora do processo, um dano de difícil ou impossível reparação."73

Ademais, não se trata de imposição da lei em que o requerente da tutela deve se atentar em garantir para ver sua pretensão deferida, ou seja, não é um pressuposto para que se conceda a medida, é uma faculdade do juiz. Nesse diapasão, a caução pode ser requerida pela parte ou exigida de ofício pelo magistrado, este incumbido de verificar o risco de assunção de eventuais prejuízos para ambas as partes, em razão do deferimento ou

\footnotetext{
${ }^{69}$ MARINONI, Luiz Guilherme; ARENHART, Sérgio Cruz; MITIDIERO, Daniel. Código de processo civil comentado. 4. ed. São Paulo: Thomson Reuters Brasil, 2018. p. 413

${ }^{70}$ RIBEIRO. Leonardo Ferres da Silva. Tutela Provisória. In: WAMBIER, Luiz Rodrigues; WAMBIER, Teresa Arruda Alvim (coords.). Temas essenciais do novo CPC: análise das principais alterações do sistema processual civil brasileiro. São Paulo: Editora Revistas dos Tribunais, 2016. p. 213

${ }^{71}$ SOUZA, Artur César de. Tutela provisória: tutela de urgência e tutela de evidência. 2. ed. São Paulo: Almedina, 2017. p. 194-195; THEODORO JÚNIOR, Humberto. Curso de direito processual civil: Teoria geral do processo civil, processo de conhecimento e procedimento comum. 59. ed. Rio de Janeiro: Forense, 2018. v. 1. p. 660

72 WAMBIER, Luiz Rodrigues; TALAMINI, Eduardo. Curso avançado de direito processual civil: Teoria Geral do Processo e Processo de Conhecimento. 15. ed. São Paulo: Revista dos Tribunais, 2016. v. 1. p. 885

${ }^{73}$ CÂMARA, Alexandre Freitas. O novo processo civil brasileiro. 3. ed. São Paulo: Atlas, 2017. p. 145. Disponível em: <https://bit.ly/2qgN1xp> Acesso em: 21 set. 2018
} 
indeferimento da medida. ${ }^{74}$ Para exigir a contracautela, o juiz deve considerar as circunstâncias de cada caso, como "[...] os riscos de geração de danos graves com a concessão da medida; os bens jurídicos que serão protegidos pela medida [...]”, bem como "[...] a possibilidade de o autor prestar caução [...]" ${ }^{75}$

Nesse momento, ressalta Araújo que o juiz não pode exigir uma garantia a tornar impossível ou muito difícil a concretização da tutela, de maneira que "[...] deve ser motivada e razoável em face do teor da medida de urgência concedida, do objeto litigioso tutelado e da possibilidade econômica daquele que pleiteia tutela." O bem-posto a garantir os danos deve ser apreciado pelo juiz a fim de apurar a sua qualidade, sob critérios como o "[...] valor, conservação e solvabilidade [...]". ${ }^{76}$

Para Medina, a depender da caução exigida pelo magistrado, pode-se tornar inviável a efetivação da tutela, por isso "[...] a caução deve ser idônea [...]", de modo a considerar a adequação da garantia, a natureza da tutela pleiteada e as condições do autor. ${ }^{77}$ Observados esses critérios, permite a lei a apresentação de caução real, a exemplo da hipoteca, penhor ou anticrese, ou fidejussória, no caso de garantia pessoal como a fiança. ${ }^{78}$ A caução real, na prática, pode ser apurada como o oferecimento de bem imóvel ou móvel, bem como o compromisso de compra e venda registrado. ${ }^{79}$

Como mencionado, o magistrado deverá avaliar a capacidade econômica da parte, porquanto pode ser dispensada a exigibilidade da caução para os que comprovarem hipossuficiência econômica, uma vez que o ônus financeiro não pode obstaculizar o acesso à jurisdição ${ }^{80}$ Explica Silva que "[...] a situação econômica e social do Brasil faz com que maioria dos brasileiros não tenha condições financeiras de prestar caução." Sob esse viés, sua obrigatoriedade não permitiria o acesso dos mais pobres às medidas cautelares. ${ }^{81}$

\footnotetext{
${ }^{74}$ THEODORO JÚNIOR, Humberto. Curso de direito processual civil: Teoria geral do processo civil, processo de conhecimento e procedimento comum. 59. ed. Rio de Janeiro: Forense, 2018. v. 1. p. 660

${ }^{75}$ WAMBIER, Luiz Rodrigues; TALAMINI, Eduardo. Curso avançado de direito processual civil: Teoria Geral do Processo e Processo de Conhecimento. 15. ed. São Paulo: Revista dos Tribunais, 2016. v. 1. p. 885

${ }^{76}$ ARAÚJO, Fabio Caldas de. Curso de processo civil: parte geral. São Paulo: Malheiros, 2016. p. 985

${ }^{77}$ MEDINA, José Miguel Garcia. Curso de direito processual civil moderno. 3. ed. São Paulo: Revistas dos Tribunais, 2017. p. 489

${ }^{78}$ SOUZA, Artur César de. Tutela provisória: tutela de urgência e tutela de evidência. 2. ed. São Paulo: Almedina, 2017. p. 198

${ }^{79}$ ARAÚJO, Fabio Caldas de. Curso de processo civil: parte geral. São Paulo: Malheiros, 2016. p. 985

${ }^{80}$ WAMBIER, Luiz Rodrigues; TALAMINI, Eduardo. Curso avançado de direito processual civil: Teoria Geral do Processo e Processo de Conhecimento. 15. ed. São Paulo: Revista dos Tribunais, 2016. v. 1. p. 885

${ }^{81}$ SILVA, Jaqueline Mielke. A tutela provisória no novo código de processo civil. 2. ed. Porto Alegre: Verbo Jurídico, 2016. p. 97
} 
A seguir serão apresentadas as considerações finais da presente pesquisa, de acordo com a fundamentação teórica apresentada.

\section{CONSIDERAÇÕES FINAIS}

Verificou-se no decorrer do artigo os principais aspectos da tutela provisória. Apurou-se as particularidades de cada modalidade, as fundadas em urgência e em evidência, bem como as regras destinadas a ambas. Tratou-se, também, da possibilidade de recebimento de uma tutela provisória quando requerida outra modalidade, a que se denomina de fungibilidade. E, no último tópico, sobre os limites do poder geral de cautela concedido ao juiz para determinar as formas de efetivação das medidas, bem como a garantia denominada contracautela.

A relevância desta pesquisa está de acordo com a temática proposta no sentido de esclarecer eventual dúvida quanto às possibilidades jurídicas proporcionadas pela tutela provisória como, por exemplo, a correta fundamentação dos requisitos essenciais. Em função disso, a tutela provisória serve como base para a melhor proteção dos direitos quando a lesão se mostra iminente e irreparável.

Este artigo científico teve como propósito apresentar, de forma concisa, uma compreensão dos principais pontos da tutela provisória, a serem observados por todos os operadores do direito para o exercício de suas atividades. Para alcançar este objetivo, explicou-se os elementos essenciais do tema de maneira concatenada e lógica, com intuito de compartilhar o conhecimento de maneira didática. Aguarda-se que a contribuição possa engajar e incitar o estudo mais aprofundado do processo civil.

\section{REFERÊNCIAS:}

AMENDOEIRA JÚNIOR, Sidnei. Fungibilidade de meios. São Paulo: Atlas, 2008.

ARAÚJO, Fabio Caldas de. Curso de processo civil: Parte geral. São Paulo: Malheiros, 2016.

ASSIS, Araken de. Processo civil brasileiro: parte geral: institutos fundamentais. 2. ed. São Paulo: Revista dos Tribunais, 2016. v. 2. 
BRASIL. Lei n ${ }^{\circ} 13.105$ de 16 de março de 2015. Código de processo civil. 2015 Disponível em: <https://bit.ly/1VojI3i> Acesso em: 25 out. 2018.

BUENO, Cassio Escarpinella. Manual de direito processual civil. 4. ed. São Paulo: Saraiva, 2018.

CÂMARA, Alexandre Freitas. O novo processo civil brasileiro. 3. ed. São Paulo: Atlas, 2017. Disponível em: <https://bit.ly/2qgN1xp> Acesso em: 21 set. 2018.

CARACIOLA, Andrea Boari; DELLORE, Luiz. Antecipação da Tutela Ex Oficcio. In: BUENO, Cássio Scarpinella (coord.). Tutela provisória no novo CPC. São Paulo: Saraiva, 2016.

DIDIER JÚNIOR. Fredie; BRAGA, Paula Sarno; OLIVEIRA, Rafael Alexandre de. Curso de direito processual civil: teoria da prova, direito probatório, decisão, precedente, coisa julgada e tutela provisória. 13. ed. Salvador: Jus Podivm, 2018. v. 2.

HERTEL, Daniel Roberto. As astreintes e o novo Código de Processo Civil. Revista Jus Navigandi, Teresina, ano 23, n. 5407, 21 abr. 2018. Disponível em: <https://bit.ly/2TaoIyE> Acesso em: 8 nov. 2018.

LAMY, Eduardo de Avelar. Princípio da fungibilidade no processo civil. São Paulo: Dialética, 2007.

MARINONI, Luiz Guilherme; ARENHART, Sérgio Cruz; MITIDIERO, Daniel. Código de processo civil comentado. 4. ed. São Paulo: Thomson Reuters Brasil, 2018.

MARINONI, Luiz Guilherme. Tutela de urgência e tutela da evidência. 2. ed. São Paulo: Thomson Reuters Brasil, 2018.

MEDINA, José Miguel Garcia. Curso de direito processual civil moderno. 3. ed. São Paulo: Editora Revistas dos Tribunais, 2017.

MELO, Manuel Maria Antunes de. Manual de direito processual civil. 2. ed. São Paulo: Edijur, 2016.

MONTENEGRO FILHO, Misael. Direito processual civil. 13. ed. São Paulo: Atlas, 2018. Disponível em: <https://bit.ly/2EPi4L0> Acesso em: 20 de set. 2018.

MOUZALAS, Rinaldo; TERCEIRO NETO, João Otávio; MADRUGA, Eduardo. Processo civil. 10. ed. Salvador: JusPodivm, 2018.

NEVES, Daniel Amorim Assumpção. Novo código de processo civil comentado. 2. ed. Salvador: JusPodivm, 2017. 
PINHO, Humberto Dalla Bernardina de. Direito processual civil contemporâneo: teoria geral do processo. 8. ed. São Paulo: Saraiva Educação, 2018.

RIBEIRO, Leonardo Ferres da Silva. Tutela Provisória. In: WAMBIER, Luiz Rodrigues; WAMBIER, Teresa Arruda Alvim (coords.). Temas essenciais do novo CPC: análise das principais alterações do sistema processual civil brasileiro. São Paulo: Editora Revistas dos Tribunais, 2016.

SÁ, Renato Montans de. Manual de direito processual civil. 3. ed. São Paulo: Saraiva, 2018. SILVA, Jaqueline Mielke. A tutela provisória no novo Código de Processo Civil. 2. ed. Porto Alegre: Verbo Jurídico, 2016.

SILVA, Ovídio A. Baptista da. A cautelar inominada no direito brasileiro. Rio de Janeiro: Forense, 1991.

SOUZA, Artur César de. Tutela provisória: tutela de urgência e tutela de evidência. 2. ed. São Paulo: Almedina, 2017.

TARDIN, Luiz Gustavo. Fungibilidade das tutelas de urgência. São Paulo: Revistas dos Tribunais, 2006.

THEODORO JÚNIOR, Humberto. Curso de direito processual civil: teoria geral do processo civil, processo de conhecimento e procedimento comum. 59. ed. Rio de Janeiro: Forense, 2018. v. 1.

VASCONCELOS, Rita de Cássia Corrêa de. Princípio da fungibilidade: hipóteses de incidência no processo civil brasileiro contemporâneo. São Paulo: Revista dos Tribunais, 2007.

VASCONCELOS, Rita de Cássia Corrêa de. A fungibilidade das tutelas provisórias. In: BUENO, Cássio Scarpinella (coord.). Tutela provisória no novo CPC. São Paulo: Saraiva, 2016.

WAMBIER, Luiz Rodrigues; TALAMINI, Eduardo. Curso avançado de direito processual civil: teoria geral do processo e processo de conhecimento. 15. ed. São Paulo: Revista dos Tribunais, 2016. v. 1.

WAMBIER, Luiz Rodrigues; TALAMINI, Eduardo. Curso avançado de processo civil: cognição jurisdicional (processo comum de conhecimento e tutela provisória). 16. ed. São Paulo: Revista dos Tribunais, 2016. v. 2.

WATANABE, Kazuo. Da cognição do processo civil. 2. ed. Campinas: Bookseller, 2000. 
Revista Eletrônica de Direito Processual - REDP.

Rio de Janeiro. Ano 16. Volume 23. Número 1. Janeiro a Abril de 2022

Periódico Quadrimestral da Pós-Graduação Stricto Sensu em Direito Processual da UERJ

Patrono: José Carlos Barbosa Moreira (in mem.). ISSN 1982-7636. pp. 599-621

www.redp.uerj.br

ZAVASCKI, Teori Albino. Antecipação da tutela. São Paulo: Saraiva, 2009. 